\title{
THE 30th ANNIVERSARY OF ERADICATION OF BOVINE TUBERCULOSIS IN CATTLE IN CZECHOSLOVAKIA
}

\author{
M. PAVLAS \\ State Veterinary Institute, Brno, Czech Republic
}

Received December 8, 1998

Accepted March 31, 1999

Abstract

Pavlas M.: The 30th Anniversary of Eradication of Bovine Tuberculosis in Cattle in Czechoslovakia. Acta Vet. Brno 1999, 68: 155-162.

Thirty years ago, in 1968, tuberculosis eradication programme was successfully finished, and the disease was eliminated from cattle herds on the whole territory of Czechoslovakia. Its prevalence in cattle decreased from $21.29 \%$ to $0.03 \%$ within seven years. When the programme with stringent control measures was initiated, $92 \%$ of cattle herds were positive for tuberculosis.

The eradication was successful above all due to isolation of infected animals, separate keeping of young cattle, immediate culling of animals with manifest clinical tuberculosis. Of great importance was also good coordination of the programme with veterinarians, farmers, epidemiologists, contract purchasers, chemical and machine industry, state administration, and financial support provided by the state amounting to 1 billion and 52 millions of crowns.

Another important outcome of this eradication programme was a decrease of the disease in cattle but also in other animal species, and above all, in man. Its remarkable efficacy and economic impact was of great importance not only in animal production but also in public health context because the prevalence of Mycobacterium bovis in humans decreased from $10 \%$ to less than one tenth after the programme was finished.

Bovine tuberculosis, prevalence, method of eradication

In October 1968, zero prevalence of bovine tuberculosis in the whole Czechoslovakia was achieved after the eradication programme in cattle herds had been successfully implemented. In Slovakia, this success was achieved one year earlier, in 1967.

The endeavours aimed at the eradication of bovine tuberculosis reach deep into the last century. The spread of this anthropozoonosis was documented by examinations of slaughtered cattle and from 1896 also by allergy tests for diagnosis that just began to be used. Until 1914, a total number of 24959 cattle were examined by tuberculin tests in Moravia, $15.58 \%$ of which tested positive. High incidence of tuberculosis in animals and especially in cattle adversely affected the state of health of human population, too. In 1882, i.e. in the era of R. Koch's discovery of the causative agent of tuberculosis, this infection was responsible for the death of every seventh man.

In the years 1910 to 1921 , tuberculosis was found in $2.4 \%$ of slaughtered cattle, and every tenth cow suffered from tuberculosis of the udder. This disconsolate epizootiological situation after the World War I was aggravated by the fact that until 1922 hardly any animals manifesting clinical tuberculosis were culled and slaughtered as requested by the official regulation. During the period of tuberculosis control according to the paragraph 46 of the Animal Infections Act, 3261 crowns a year were paid by way of state compensation from 1910 to 1921 in the Czech lands. During the first years after the World War I, the Act No. 177 of 6th August 1909 was in force, which replaced the Act of 20th February 1880 in historic countries of the Czechoslovak Republic. According to the procedural regulation cattle suffering from progressive clinical tuberculosis manifested in lungs, intestines, uterus, and udder were notifiable. For the purpose of remuneration of damage caused by notifiable diseases including tuberculosis Dr. Živ ot ský (1923) proposed a stamp-duty on accompanying documents for cattle.

Address for correspondence:

Doc. MVDr. Milan Pavlas, DrSc.

Doc. MVí vetrinární ústav

Palackého 174, 61238 Brno, Czech Republic
Phone: +420541321229

http://www.vfu.cz/acta-vet/actavet.htm 
We can imagine the prevalence of tuberculosis after the World War I from data on slaughtered cattle. From 1921 to 1930 it was found in $2.8 \%$ of cattle (Harnach 1932). This relatively low occurrence of tuberculosis was caused by its low prevalence in calves $(1.02$ $\%$ ) that made up $50 \%$ of slaughtered cattle. According to the above-mentioned author, tbc changes at the inspection after slaughter were found in $5.5 \%$ and $46.72 \%$ of cattle older than 6 weeks and 6 years, respectively. Other authors came to similar conclusions (Klobouk 1923; Doubrava 1933). From 1923 to 1935, according to Doubrava, a total number of 20339 cattle were subjected to tuberculin tests and 1618 and 286 individuals tested positive (i.e. $7.95 \%$ ) and dubious (1.4\%), respectively.

Control of tuberculosis in cattle herds was the most urgent task from the very beginning of the Czechoslovak Republic both because of profitability and human and other animal's health. During this period, however, there were no conditions created for effective whole-state control of this dangerous infection. In 1919 Prof. Honl, the founder of Czechoslovak bacteriology and serology, initiated the Czechoslovak Scientific Association against Tuberculosis, which the veterinary section was part of. In 1923 this association organised, at Prof. Honl instance, the First Czechoslovak anti-tuberculosis congress in Prague.

At the first meeting of the third (veterinary) section of the Czechoslovak Scientific Association against Tuberculosis which took place on 20th and 21st May 1923 in Prague, the most important problems concerning the combat of cattle tuberculosis pointed out (Klobouk 1923). Prof. Klobouk considered early diagnosis of the most dangerous open forms, i.e. tuberculosis of the mammary gland and respiratory tract, to be of paramount importance. At the same time, however, he considered diagnosis of early forms of the infection, clinically not manifested yet, to be the most difficult diagnostic problem.

Regarding the possible failure of tuberculin testing, false-positive results of allergy tests, an uncompromising requirement was emphasised for the completeness of examination of animals for tuberculosis. The production of sensitive and specific tuberculins that would guarantee reproducible and comparable results was considered as a precondition for effective combat of tuberculosis.

In 1936, a total number of 1679 (i.e. $23.8 \%$ ) were tuberculin-positive out of 7053 head of cattle examined in 54 Czech municipalities. While in small farmyards the disease occurred in one quarter of all herds, in large-scale farms the disease was diagnosed in all herds (Voráček 1936).

As far as the immuno-prophylactic measures were concerned, Prof. Klobouk was convinced that cattle vaccination might help to control the infection during the first phase of control measures in those herds, in which it was not possible immediately to cull or separate all infected animals. Encouraging results by Calmette and Guérin (Calmette 1922, 1928; Guérin 1927) were supplemented by Prof. Klobouk (1929) who verified the vaccine safety in cattle and small ruminants. His results proved that the vaccine was safe, and the process was initiated for the approval of cattle vaccination by the Ministry of Agriculture Regulation of 28th February 1934 No. 10420-Z/1934. Provincial authorities were in charge of permitting BCG vaccination under certain preconditions. Unfortunately, until 1943, the whole undertaking was not exactly documented so that it was impossible to evaluate the efficacy of vaccination. The above-mentioned regulation of 1934 was supplemented nearly 10 years later by instructions of the Ministry of the Interior of the Protectorate of Bohemia and Moravia of 10th December 1943 No. 12184/1943- IV/1, which listed the conditions of permitting the BCG vaccination on a voluntary basis. The vaccination was approved of by the Provincial Authority following a breeder's request. Vaccination was only permitted after tuberculin testing by an official veterinarian. The breeders shared the costs of vaccination and examination of animals by paying 10 crowns per every animal vaccinated. All the other 
costs were paid for by the Provincial Authority using the money set aside for the item 9, which was intended for the control of diseases that were not notifiable infections. Because of war events the vaccination against tuberculosis was stopped in 1944, thus making it again impossible to evaluate its efficacy.

During World War II cattle examinations for tuberculosis were organised by the Czech Agricultural Council, later the Provincial Agricultural and Forestry Union of Bohemia and Moravia in Prague together with milk yield control. In those times tuberculosis was found in $19.3 \%$ of cattle from 5680 herds, i.e. in $35.5 \%$ of farms. The highest prevalence of tuberculosis was found in large-scale farms with tuberculin-positive results as high as to 20 to $75.5 \%$ (Hynek 1942; Hökl and Prokůpek 1943).

An important finding was made at the department of Prof. Klobouk during World War II, namely, that cattle infected with tuberculosis and positive for the mammalian tuberculin may pass Mycobacterium bovis in their faeces or urine without any microscopic changes indicative of tuberculosis affecting the gastrointestinal or urinary tracts (Hynek 1942). Therefore emphasis was laid on the fact that any animal infected and sufferring from bovine tuberculosis regardless of the extent and localisation of specific changes might become the source of infection. This piece of knowledge was considered as one of the most important preconditions for an effective cattle tuberculosis control.

During the post-war years up to 1948 the epizootiological situation remained nearly the same. Forced and hasty collectivization of agriculture lead to considerable impairment of the state of health in cattle with regard to the epizootic diseases, tuberculosis included (due to animal transfers, neglect etc.). Of the total number of cattle kept in the country, the numbers in tuberculosis-free herds formed only $9.4 \%$ and $11.1 \%$ in agricultural cooperative farms and state farms, respectively. The milk yield of cows in affected herds was 10 to $25 \%$ lower compared to unaffected infection-free herds. Damage caused by tuberculosis during the 1950s exceeded three quarters of billion crowns a year. A state programme for control of tuberculosis was therefore prepared.

Regulations for the control were instituted. They were based on a detailed epizootiological analysis made along with verification of suitable methods and collection of scientific data, including economic and health aspects necessary to enforce and gain support for the eradication plans. Elimination and control measures were prepared in close cooperation and co-ordination of veterinarians and other professionals. The proposal for control measures was published in the professional journal Veterinářství in April 1955 together with a request for comments and further recommendations from the field. These were sent by veterinarians to the Veterinary Administration of the Ministry of Agriculture or to the Editorial Office of the journal. The best comments were published in the journal, and included in the prepared materials. The proposal for the control and protection of farm animals from tuberculosis prepared by the State Veterinary Administration of the Ministry of Agriculture and Forestry (Kraus 1955) became the basic material for legal regulations outlining the procedures necessary for Tbc control in farm animals including sheep, goats, pigs and poultry, set by the governmental decree No. 3593 of 21st December 1955. In this decree, the Ministry of Agriculture and Forestry was imposed with a duty to launch regular veterinary examinations of domestic and farm animals aimed at tuberculosis. During the first phase this concerned breeding regions and cattle intended for the production of powdered and fresh milk for children and for patients. All veterinary procedures necessary for the large-scale preventive examinations and control of tuberculosis were done free of charge and were paid for from financial resources of the Ministry of Agriculture and Forestry in agreement with regulations on the control and preventive measures against tuberculosis of animals No. 100, the item 21/1956 of the Bulletin of the Ministry of Agriculture and Forestry. 
The Clinic of infectious diseases at the Veterinary Faculty of the Agricultural University in Brno was founded in 1952. Professor Klobouk was appointed its Head. The purpose of its existence was to improve the instruction for students in infectious diseases and herd management. Apart from teaching students, this clinic was engaged in research projects. The main project at that time was to optimise the intravital diagnosis of tuberculosis and to verify the efficacy of M and BCG vaccines against tuberculosis of cattle under field conditions (Pavlas and Hejlíček 1957; Rossi 1957; Pavlas 1963). The above-mentioned experiments were based on the results gained in tests on the immunogenic characteristics of the BCG and M vaccines in humans and animals (Klobouk 1929; Šula et al. 1953; Zbořil 1953; Václavík 1953). Results achieved in the field of allergenodiagnosis explained the importance of double tests, above all, in animals with attenuated allergy or with less sensitive tuberculins were summarised in the last paper by Prof. Klobouk and published in the journal Veterinářství (Klobouk and Pavlas 1957).

To further support the scientific approach to solution of this nationwide problem, in 1958 the Laboratory for Research of Bovine Tuberculosis was founded at the Veterinary Research Institute in Brno. The laboratory contributed to the launching of bivalent mammalian PPD tuberculins that replaced the trivalent tuberculin "vetus". This PPD tuberculin was standardised with international standards using biological titration (Pavlas 1958). A sampling device for collection of sputum was developed and manufactured (Schneeweis and Pavlas 1959). It proved helpful in diagnosis of open forms of lung tuberculosis. In order to explain non-specific reactions to the mammalian tuberculin, the method of simultaneous tuberculination was improved and parameters for effective milk pasteurisation determined (Pavlas 1962). More effective disinfection means were introduced for decontamination of stables (Pavlas 1961). Furthermore, the reliability of serologic diagnosis in animals not reacting to tuberculin, immunoprophylaxis and chemoprophylaxis of cattle imminently threatened by tuberculosis were verified (Pavlas 1963, 1965). Daily educational work among workers in the agriculture to support and ensure the long-term eradication programme included slides, film clips and publications. The State Insurance Company participated in production of these materials (Klobouk et al. 1959; Dražan et al. 1962).

The methodical and legislation basis for tuberculosis control in farm animals was finished in 1959 and the governmental decree No. 781/59 was issued. At the suggestion of the Ministry of Agriculture gradual control of tuberculosis on the whole territory of the state until its complete eradication was imposed. In 1959 for the first time, large-scale tuberculin testing in all cattle herds was performed. The Veterinary Care Act No. 66/61 Coll. became the other legal basis for elimination of bovine tuberculosis. The governmental decree No. 1059 of December 1961 imposed measures for ensuring safety of milk and the decree No. 673 of July 1962 issued other measures that were necessary to implement the programme of elimination of bovine tuberculosis in a shortened term, i.e. to decrease the prevalence of tuberculosis in cattle by half by the end of 1965 and to reach zero prevalence of this infection in the whole country by 1968 .

The importance of this goal is illustrated in Fig. 1 showing the situation in 1961: the occurrence of tuberculosis in cattle reached $21.3 \%$ in the whole Czechoslovakia, $32.94 \%$ in cows, $21.75 \%$ in heifers, and $5.66 \%$ in calves. Its prevalence in state farms reached $45.89 \%$ in cattle, $66 \%$ in cows, $33.57 \%$ in heifers and $16.53 \%$ in calves. During this period cattle tuberculosis was found in $86 \%$ of cooperative farms and $85 \%$ of state farms. The considerable extent of the disease in cattle herds was also documented by reports according to which the number of cattle in cooperative and state farms free of tuberculosis was only 9.4 to $11 \%$ (Kouba 1959). The lowest prevalence of tuberculosis was found in private farms with the occurrence in cattle reaching $8.61 \%$, i.e. $10.87 \%$ of cows, $4.62 \%$ of heifers, 
and $1.21 \%$ of calves. This situation in the private sector corresponded with the prevalence in cattle during the first post-war decade as mentioned by Professor Harnach (1932).

During the first phase of implementing the control measures it was necessary to raise breeding calves also from dams that were suspected from being infected or were infected. Apart from largescale tuberculin tests reaching over 5 million allergy tests a year, some animals were examined clinically and if needed, their milk, sputum, uterine discharge or other samples were collected for laboratory examinations. During one year, a total number of 34968 animals were culled for progressive tuberculosis. The efficacy of these activities was documented by the

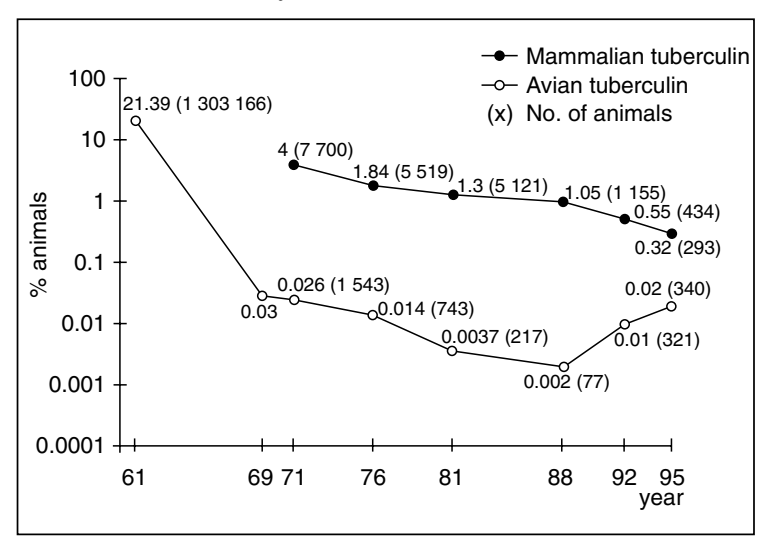

Fig. 1. Prevalence of reactors for the mammalian and avian tuberculin in cattle in Czechoslovakia in 1961 to 1995.

fact that in 1959 the infection was brought under control in 998 cooperative and state farms. In 1961, according to data from the the State Veterinary Administration, $93.7 \%$ of cattle testing positive for tuberculin were isolated into isolation stables. The high prevalence of cattle tuberculosis found by tuberculin tests corresponded with findings at the slaughter inspection of cattle amounting to $22 \%$ in 1961 and nearly to $23 \%$ in 1962.

The number of herds free from tuberculosis in 1961 amounted to $8 \%$ and other $12.3 \%$ were under observation with no animals suspect of infection. The efficacy of separate keeping cattle infected by tuberculosis led to a decrease in numbers of positive reactors for the mammalian tuberculin from $10.6 \%$ in 1959 to $3.3 \%$ in 1961 . With the increasing number of tuberculosis-free herds, only cows free of infection were used for production of breeding heifers. Strict isolation of infected animals, manufacture of tuberculins with high sensitivity and specifity, immediate culling of cattle showing clinical forms of the disease, devoted work of veterinarians, epidemiologists, farmers and other workers enabled the decrease of tuberculosis to nearly zero prevalence within 7 years, i.e until 1968.

The final goal of bovine tuberculosis elimination was reached due to successful coordination of the whole programme and participation of veterinarians, farmers, epidemiologists, contract purchasers in agriculture, chemical and machine industry, state administration, and financial support amounting to 1 billion and 52 millions crowns (Polák 1969). Tuberculosis was found in $8.1 \%$ and $2.9 \%$ of cattle slaughtered in 1967 and 1968 , respectively. Further considerable decrease of tuberculosis findings at inspection of slaughtered animals was noted in the following years (i.e. $0.84 \%$ and $0.6 \%$ in 1969 and 1970 , respectively). Occasional new cases of tuberculosis in herds that were freed from the infection were caused mainly by animals with latent tuberculosis showing no reaction to tuberculin, free-living animals and man (Popluhár and Vrtiak 1966; Pavlas et al. 1966; Rossi and Dokoupil 1969).

Eradication of bovine tuberculosis in cattle had a beneficial effect in other animal species and man, as well; for example, in pigs the prevalence of tuberculosis at the inspection after slaughter dropped from $1.82 \%$ in 1959 to one half after the eradication of bovine tuberculosis (Fig. 2). In humans the prevalence of Mycobacterium bovis decreased from the pre-war $10 \%$ to less than one tenth after the end of tuberculosis eradication programme. $M$. bovis occurrence in humans in the last years, of all the pathogenic mycobacteria found 


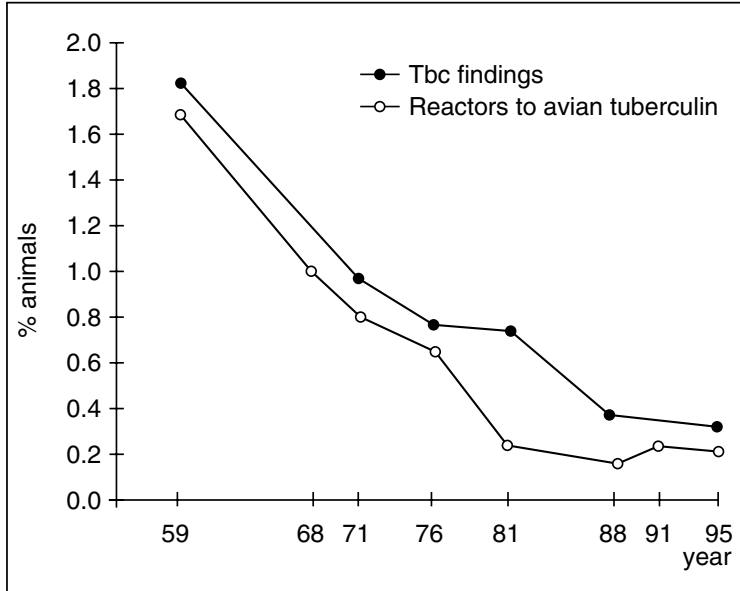

Fig. 2. Prevalence of tuberculosis and reactors to the avian tuberculin in pigs in 1959 to 1995. in humans, is of least importance from the mycobacteria strains isolated (Table 1, Fig. 3).

At present, worldwide approximately 1.7 billion of humans are infected by mycobacteria with 20 million showing clinical manifestations of the disease. Nearly 3 million humans per year die because of tuberculosis. In 1960 , the morbidity caused by tuberculosis was about 200 patients per 100000 inhabitants in Czech Lands. Until 1955, i.e. during 35 years, this morbidity decreased more than 10 times. However, in 1994, in spite of the improved epidemiological situation, a total

Table 1

Prevalence of pathogenic and opportunistic species of mycobacteria in humans in Bohemia in 1983 to 1994 (National Laboratory for Mycobacteria, Prague)

\begin{tabular}{|c|c|c|c|c|c|c|c|c|c|c|c|}
\hline \multirow[b]{2}{*}{ Year } & \multicolumn{11}{|c|}{ Numbers of primary isolations of mycobacteria } \\
\hline & Total & $\begin{array}{c}M . \\
\text { tuberc. }\end{array}$ & $\begin{array}{l}\text { M. } \\
\text { bovis }\end{array}$ & $\begin{array}{c}M . \\
\text { avium }\end{array}$ & $\begin{array}{c}\text { M. } \\
\text { szulgai }\end{array}$ & $\begin{array}{c}M . \\
\text { kansasii }\end{array}$ & $\begin{array}{c}M . \\
\text { xenopi }\end{array}$ & $\begin{array}{c}M . \\
\text { fortuitum }\end{array}$ & $\begin{array}{c}\text { M. } \\
\text { chelonae }\end{array}$ & $\begin{array}{c}M . \\
\text { scroful. }\end{array}$ & $\begin{array}{c}M . \\
B C G\end{array}$ \\
\hline 1983 & $\begin{array}{l}2426 \\
100 \%\end{array}$ & $\begin{array}{c}2203 \\
90.8 \%\end{array}$ & $\begin{array}{c}16 \\
0.7 \%\end{array}$ & $\begin{array}{c}29 \\
1.2 \%\end{array}$ & & $\begin{array}{c}151 \\
6.23 \%\end{array}$ & $\begin{array}{c}17 \\
0.7 \%\end{array}$ & $\begin{array}{c}8 \\
0.3 \%\end{array}$ & & & \\
\hline 1984 & $\begin{array}{l}2475 \\
100 \% \\
\end{array}$ & $\begin{array}{c}2182 \\
88.2 \% \\
\end{array}$ & $\begin{array}{c}14 \\
0.6 \% \\
\end{array}$ & $\begin{array}{c}37 \\
1.5 \% \\
\end{array}$ & & $\begin{array}{c}136 \\
5.5 \% \\
\end{array}$ & $\begin{array}{c}16 \\
0.6 \% \\
\end{array}$ & $\begin{array}{c}11 \\
0.4 \% \\
\end{array}$ & & & \\
\hline 1985 & $\begin{array}{l}2068 \\
100 \%\end{array}$ & $\begin{array}{c}1796 \\
86.9 \% \\
\end{array}$ & $\begin{array}{c}4 \\
0.2 \% \\
\end{array}$ & $\begin{array}{c}19 \\
0.9 \% \\
\end{array}$ & & $\begin{array}{c}136 \\
6.6 \% \\
\end{array}$ & $\begin{array}{c}29 \\
1.4 \% \\
\end{array}$ & $\begin{array}{c}17 \\
0.8 \% \\
\end{array}$ & & & \\
\hline 1986 & $\begin{array}{c}1947 \\
100 \%\end{array}$ & $\begin{array}{c}1647 \\
84.6 \%\end{array}$ & $\begin{array}{c}7 \\
0.3 \%\end{array}$ & $\begin{array}{c}21 \\
1.1 \%\end{array}$ & & $\begin{array}{c}124 \\
6.4 \%\end{array}$ & $\begin{array}{c}91 \\
4.7 \%\end{array}$ & & $6 \%$ & $\stackrel{2}{2} 0.1 \%$ & \\
\hline 1987 & $\begin{array}{l}1840 \\
100 \%\end{array}$ & $\begin{array}{c}1521 \\
82.7 \%\end{array}$ & $\begin{array}{c}5 \\
0.3 \%\end{array}$ & $\begin{array}{c}23 \\
1.2 \%\end{array}$ & & $\begin{array}{c}119 \\
6.5 \%\end{array}$ & $\begin{array}{c}104 \\
5.7 \%\end{array}$ & & $6 \%$ & $\begin{array}{c}2 \\
0.1 \%\end{array}$ & \\
\hline 1988 & $\begin{array}{c}1699 \\
100 \%\end{array}$ & $\begin{array}{c}1469 \\
80.5 \%\end{array}$ & $\begin{array}{c}8 \\
0.4 \%\end{array}$ & $\begin{array}{c}32 \\
1.7 \%\end{array}$ & & $\begin{array}{c}114 \\
6.2 \%\end{array}$ & $\begin{array}{c}61 \\
3.3 \%\end{array}$ & & $\begin{array}{l}15 \\
8 \%\end{array}$ & 0 & \\
\hline 1989 & $\begin{array}{c}1965 \\
100 \%\end{array}$ & $\begin{array}{c}1503 \\
76.5 \%\end{array}$ & $\begin{array}{c}8 \\
0.4 \%\end{array}$ & $\begin{array}{c}48 \\
2.4 \%\end{array}$ & & $\begin{array}{c}121 \\
6.4 \%\end{array}$ & $\begin{array}{c}74 \\
3.8 \%\end{array}$ & & $7 \%$ & $\begin{array}{c}1 \\
0.05 \%\end{array}$ & \\
\hline 1990 & $\begin{array}{l}2210 \\
100 \%\end{array}$ & $\begin{array}{c}1498 \\
67.8 \%\end{array}$ & $\begin{array}{c}7 \\
0.3 \%\end{array}$ & $\begin{array}{c}33 \\
1.5 \%\end{array}$ & & $\begin{array}{c}148 \\
6.7 \%\end{array}$ & $\begin{array}{c}76 \\
3.4 \%\end{array}$ & & $5 \%$ & $\begin{array}{c}3 \\
0.1 \%\end{array}$ & \\
\hline 1991 & $\begin{array}{l}2239 \\
100 \%\end{array}$ & $\begin{array}{c}1541 \\
68.8 \%\end{array}$ & $\begin{array}{c}8 \\
0.4 \%\end{array}$ & $\begin{array}{c}31 \\
1.4 \%\end{array}$ & & $\begin{array}{c}141 \\
6.3 \%\end{array}$ & $\begin{array}{c}97 \\
4.4 \%\end{array}$ & & 31 & $\begin{array}{c}2 \\
0.1 \%\end{array}$ & \\
\hline 1992 & $\begin{array}{l}2274 \\
100 \%\end{array}$ & $\begin{array}{c}1412 \\
62.1 \%\end{array}$ & $\begin{array}{c}8 \\
0.4 \%\end{array}$ & $\begin{array}{c}35 \\
1.4 \%\end{array}$ & & $\begin{array}{c}122 \\
5.4 \%\end{array}$ & $\begin{array}{c}76 \\
3.4 \%\end{array}$ & & 96 & $\begin{array}{c}4 \\
0.2 \%\end{array}$ & \\
\hline 1993 & $\begin{array}{l}2143 \\
100 \%\end{array}$ & $\begin{array}{c}1216 \\
56.8 \%\end{array}$ & $\begin{array}{c}6 \\
0.3 \% \\
\end{array}$ & $\begin{array}{c}33 \\
1.5 \%\end{array}$ & 1 & $\begin{array}{c}117 \\
5.5 \%\end{array}$ & $\begin{array}{c}37 \\
1.7 \%\end{array}$ & & $\begin{array}{l}15 \\
4 \% \\
\end{array}$ & $\begin{array}{c}2 \\
0.1 \%\end{array}$ & $\begin{array}{c}148 \\
6.9 \%\end{array}$ \\
\hline 1994 & $\begin{array}{c}2298 \\
100 \% \\
\end{array}$ & $\begin{array}{c}1157 \\
50.5 \% \\
\end{array}$ & $\begin{array}{c}4 \\
0.2 \% \\
\end{array}$ & $\begin{array}{c}64 \\
2.8 \% \\
\end{array}$ & 1 & $\begin{array}{c}107 \\
4.7 \%\end{array}$ & $\begin{array}{c}62 \\
2.7 \%\end{array}$ & & $\begin{array}{l}47 \\
4 \%\end{array}$ & $\begin{array}{c}2 \\
0.1 \%\end{array}$ & $\begin{array}{c}168 \\
7.3 \%\end{array}$ \\
\hline Total & $\begin{array}{l}25584 \\
100 \% \\
\end{array}$ & $\begin{array}{c}19145 \\
74.83 \% \\
\end{array}$ & $\begin{array}{c}95 \\
0.37 \% \\
\end{array}$ & $\begin{array}{c}405 \\
1.58 \% \\
\end{array}$ & $\begin{array}{c}2 \\
0.01 \% \\
\end{array}$ & $\begin{array}{c}1536 \\
6 \% \\
\end{array}$ & $\begin{array}{c}740 \\
2.89 \% \\
\end{array}$ & & $\begin{array}{l}73 \\
4 \% \\
\end{array}$ & $\begin{array}{c}18 \\
0.07 \% \\
\end{array}$ & $\begin{array}{c}316 \\
1.23 \% \\
\end{array}$ \\
\hline $\begin{array}{l}\text { Total } \\
\text { typed }\end{array}$ & 22830 & $83.86 \%$ & $0.43 \%$ & $1.78 \%$ & $0.01 \%$ & $6.7 \%$ & $3.25 \%$ & & $5 \%$ & $0.08 \%$ & $1.39 \%$ \\
\hline
\end{tabular}


number of 1157 strains of Mycobacterium tuberculosis (Švandová 1998) was isolated from tuberculosis patients by primary cultivation.

In recent years, however, Mycobacterium avium with its frequent source in uncontrolled small-scale flocks of poultry and free-living animals is of greatest health risk of all the mycobacteria occurring in animals. In the past, there were some sporadic cases of bovine tuberculosis found in freeliving animals or in zoo animals. Regarding the sporadic cases of $M$.

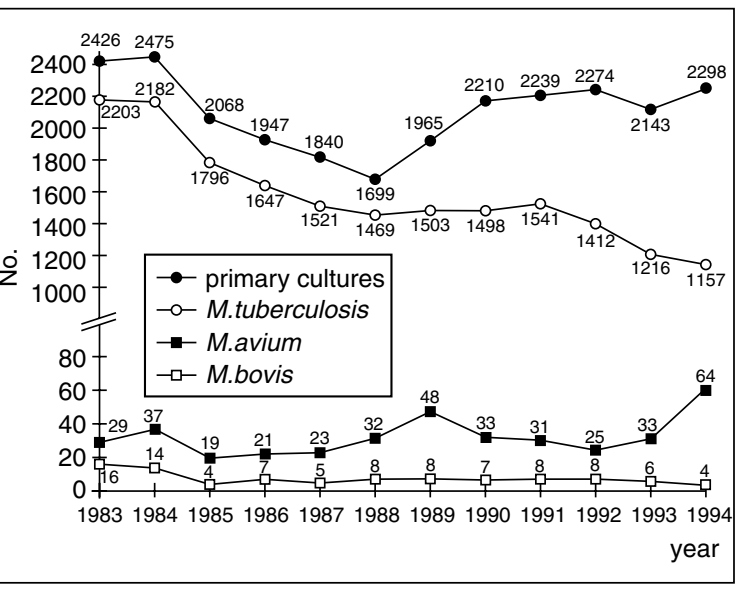

bovis in humans, we cannot exclude Fig. 3. Prevalence of M. tuberculosis, M. bovis and M. avium in sporadic occurrence of bovine humans in Bohemia between 1983 and 1994.

tuberculosis in some animals (cats, dogs, some birds and others) which are in direct contact with human patients. Sporadic sources of $M$. bovis are also wittnessed by the occurrence of last case of tuberculosis in cattle in the Czech Republic in 1995 (Pavlík et al. 1998).

With the lapse of time representing several decades from the eradication of bovine tuberculosis, it is necessary to pay homage to all the workers whose dedication and rational activities contributed considerably to the success of this radical programme. The outcome of this nation-wide goal of the veterinary profession (unlike some programmes with less consequent measures as carried out in other countries) was possible due to broad cooperation of other professions and regulatory bodies at all administration levels. Efficiently invested financial resources, organizational, scientific and research activities aimed at the most important control measures may serve as an example for solving current health problems in animals and humans.

\section{K 30. výročí utlumení tuberkulózy u skotu v Československu}

Před 30. lety v roce 1968 bylo dosaženo ozdravení chovů skotu od tuberkulózy na celém území Československa. Vprůběhu sedmi let byla snížena prevalence této nákazy u skotu z 21,29 \% na $0,03 \%$. Na začátku ozdravovací akce bylo $92 \%$ chovů skotu nakaženo tuberkulózou.

K ozdravení skotu přispěla zejména izolace zvířat nakažených tuberkulózou, oddělený odchov mladého skotu, bezodkladné vyřazování zvířat s klinickou formou tuberkulózy, úspěšná koordinace celého programu ozdravení, na kterém se podíleli veterinární lékaři, zemědělci, epidemiologové, organizace výkupu, potravinářského, chemického, strojírenského průmyslu, správní aparát a finanční podpora státu ve výši 1 miliardy 52 milionů korun.

Utlumení bovinní tuberkulózy u skotu se příznivě projevilo v poklesu této nákazy nejen u skotu, ale rovněž u dalších druhů zvířat a člověka. Prevalence u lidí poklesla z $10 \%$ na méně než jednu desetinu po ukončení eradikačního programu.

\section{References}

CALMETTE, A. 1922: L'infection bacilaire et la tuberculose. Paris 127 p.

CALMETTE, A. 1928: Über den Schutzimpfung der neugeborenen gegen Tbc durch den BCG (Calmette-Guérin) Zeitschr. f. Tbc. Bd. 50: $38-42$ 
DOUBRAVA, 0. 1933: Statistika tuberkulosy skotu v zemi moravskoslezské za léta 1923-1932. Zvěrolékařský obzor, XXVI, 9: 161-166

DRAŽAN, J., CUPÁK, M., ČERNÝ, L., DOBEŠ, M., JEDLIČKA, J., KÁBRT, J., KLIMEŠ, B., KLOBOUK, A., KOUBA, V., KUBÍK, A., MIKOTOVÁ, E., PAVLAS, M., PIVNÍK, L., PRAVDA, D., REJTHÁR, E., ROSSI, L., RYŠÁNEK, M., Ř́lHA, V., ŠTĚPÁNEK, M., ZENDULKA, M. 1962: Tuberkulóza hospodářských zvířat. SZN Praha, 509 p.

GUÉRIN, G., RICHART, A., BOISSIÉRE 1927: Essai de prophylaxie de la tuberculose bovine par le BCG dans une exploitation rurale infecté (1921-1927). Annales de l'institut Pasteur T. 41: 233-238

HARNACH, R. 1932: Tuberkulosa skotu v ČSR za desetiletí 1921-1930 a její hodnocení podle statistických nálezů na jatkách. Klinické spisy Vysoké školy zvěrolékařské: 121-155

HÖKL, J., PROKU゚PEK, K. 1943: Poznámky k intradermální alergické zkoušce na tuberkulin u skotu a koz. Zvěrolékařský obzor 5, 10: 129-135

HYNEK, B. 1942: Studie o průkazu otevřených forem tuberkulosy skotu reagujícího positivně na tuberkulin. Zvěrolékařský obzor 35: 205- 238

KLOBOUK, A. 1923: Klinické formy tuberkulosy skotu, jejich diagnosa a útlum se zřetelem k zákonitým ustanovením. Věstník I. vědeckého sjezdu protituberkulosního v Praze.

KLOBOUK, A. 1929: Pokusy s Calmetteovou vakcinou BCG. Zvěrolékařský obzor 22: 149-151

KLOBOUK, A., PAVLAS, M. 1957: Důležité problémy diagnostiky tuberkulózy při plnění celostátního úkolu v tlumení tuberkulózy u domácích zvířat. Veterinářství 7: 2-7

KLOBOUK, A., DRAŽAN, J., PAVLAS, M. 1959: Tuberkulóza hospodářských zvířat. SZN, Praha, 116 p.

KOUBA, V. 1959: Boj proti tuberkulóze skotu hlavním současným úkolem veterinární služby. Veterinářství 9: 1- 6

KRAUS, L. 1955: Návrh Nařízení o zdolávacích a ochranných opatřeních při tuberkulose hospodářských zvířat. Veterinářství 4: 119-124

PAVLAS, M., HEJLÍČEK, K. 1957: Aktivní imunizace skotu proti tuberkulóze M-vakcínou. Vet. Med. Praha 2 : 881-900

PAVLAS, M. 1958: Alergenodiagnostika při tuberkulóze skotu. Veterinářství 8:162-167

PAVLAS, M. 1961: Účinnost některých desinfekčních prostředků na Mycobacterium tuberculosis var. bovis. Vet. Med. Praha 6: 507- 512

PAVLAS, M. 1962: Termorezistence mykobakterií v mléce. Docum. vet. Brno: 21-26

PAVLAS, M. 1963a: Dynamika tvorby protilátek prokazatelných HA a HL zkouškou u skotu experimentálně nakaženého tuberkulózou. Docum. vet. Brno: 183-190

PAVLAS, M. 1963b: Imunogenní vlastnosti M-vakcíny a zkušenosti s tlumením tuberkulózy skotu pomocí aktivní imunizace. Docum. vet. Brno: 1-4

PAVLAS, M. 1965: Účinnost INH a Cykloserinu při prevenci a terapii tuberkulózy u skotu. Docum. vet. Brno: $125-138$

PAVLAS, M., STRNAD, M., PEJŠEK, V., HALÍŘ, J. 1966: Infektionskette Tier - Mensch - Tier bei Mycobacterium bovis. Praxis der Pneumologie vereinigt mit der Tuberkulosearzt. 20: 550- 559

PAVLÍK, I., BARTL, J., PARMOVÁ, I., HAVELKOVÂ, M., KUBÍN, M., BAŽANT, J. 1998: Occurrence of bovine tuberculosis in animals and humans in the Czech Republic in the years 1969 to 1996. Vet. Med. - Czech 43: $221-231$

POLÁK, L. 1969: Utlumení tuberkulózy skotu v Československé socialistické republice. Veterinářství 19: 2 - 4

POPLUHÁR, L., VRTIAK, J. 1966: Latentné formy a anergenti v úlohe zdroja tuberkulóznej infekcie u hovädzieho dobytka. Vet. Med. Praha 11: 523 - 528

ROSSI, L., DOKOUPIL, S. 1969: Vrabci (Passer domesticus) jako zdroj aviární infekce u hospodářských zvířat. Veterinářství 19: $356-358$

SCHNEEWEIS, P., PAVLAS, M. 1959: Příspěvek k diagnostice tuberkulózy plic u skotu. Vet. Med. Praha 4: $749-758$

ŠULA, L.,KUBÍN, M., ZAVADILOVÁ, Z., MEDULÁNOVÁ, L. 1953: Nová očkovací látka proti tuberkulose. Sborník ČSAZV A 26: 91 - 94

ŠVANDOVÁ, E. 1998: K historii tuberkulózy v České republice. Zprávy centra epidemiologie, SZÚ Praha 7: $273-277$

VÁCLAVÍK, O. 1953: Zkušenosti s hromadným očkováním skotu proti tbc v litovelském okrese. Veterinářství 3: $182-184$

VORÁČEK, F. 1936: Tlumení tuberkulosy skotu. Věstník II. sjezdu veterinářů ČSR, Brno, p. 125-133

ZBOŘIL, J. 1953: Vakcinácia teliat proti tuberkulóze. Veterinářství 3: 27- 28

ŽIVOTSKÝ, J. 1923: Statistika tuberkulosy skotu v Československé republice se zvláštním zřetelem k Moravě. Věstník I. čsl. vědecký sjezd protituberkulózní v Praze. 